\title{
Latin American Consensus: Children Born Small for Gestational Age
}

\author{
Margaret CS Boguszewski ${ }^{{ }^{*}+}$, Veronica Mericq ${ }^{2 \dagger}$, Ignacio Bergada ${ }^{3 \dagger}$, Durval Damiani ${ }^{4 \dagger}$, Alicia Belgorosky ${ }^{5 \dagger}$, \\ Peter Gunczler ${ }^{6 \dagger}$, Teresa Ortiz ${ }^{7 \dagger}$, Mauricio Llano ${ }^{8 \dagger}$, Horacio M Domené ${ }^{9 \dagger}$, Raúl Calzada-León ${ }^{10 \dagger}$, Armando Blanco ${ }^{11 \dagger}$, \\ Margarita Barrientos ${ }^{12 \dagger}$, Patricio Procel ${ }^{13 \dagger}$, Roberto Lanes $^{14 \dagger}$ and Orlando Jaramillo ${ }^{15 \dagger}$
}

\begin{abstract}
Background: Children born small for gestational age (SGA) experience higher rates of morbidity and mortality than those born appropriate for gestational age. In Latin America, identification and optimal management of children born SGA is a critical issue. Leading experts in pediatric endocrinology throughout Latin America established working groups in order to discuss key challenges regarding the evaluation and management of children born SGA and ultimately develop a consensus statement.

Discussion: SGA is defined as a birth weight and/or birth length greater than 2 standard deviations (SD) below the population reference mean for gestational age. SGA refers to body size and implies length-weight reference data in a geographical population whose ethnicity is known and specific to this group. Ideally, each country/region within Latin America should establish its own standards and make relevant updates. SGA children should be evaluated with standardized measures by trained personnel every 3 months during year 1 and every 6 months during year 2. Those without catch-up growth within the first 6 months of life need further evaluation, as do children whose weight is $\leq-2$ SD at age 2 years. Growth hormone treatment can begin in SGA children $>2$ years with short stature $(<-2.0 \mathrm{SD})$ and a growth velocity $<25$ th percentile for their age, and should continue until final height (a growth velocity below $2 \mathrm{~cm} /$ year or a bone age of $>14$ years for girls and $>16$ years for boys) is reached. Blood glucose, thyroid function, HbA1c, and insulin-like growth factor-1 (IGF-1) should be monitored once a year. Monitoring insulin changes from baseline and surrogates of insulin sensitivity is essential. Reduced fetal growth followed by excessive postnatal catch-up in height, and particularly in weight, should be closely monitored. In both sexes, gonadal function should be monitored especially during puberty.

Summary: Children born SGA should be carefully followed by a multidisciplinary group that includes perinatologists, pediatricians, nutritionists, and pediatric endocrinologists since 10\% to 15\% will continue to have weight and height deficiency through development and may benefit from growth hormone treatment. Standards/ guidelines should be developed on a country/region basis throughout Latin America.
\end{abstract}

\section{Background}

Low birth weight $(<2500 \mathrm{~g})$ is prevalent in many countries and poses a significant public health problem contributing to a variety of short- and long-term negative effects. While about half of low-birth-weight infants in the industrialized world are born preterm ( $<37$ weeks' gestation), most of these infants are born full term in

\footnotetext{
* Correspondence: margabogus@uol.com.br

† Contributed equally

'Department of Pediatrics, Hospital de Clínicas, Federal University of Paraná, Curitiba, Brazil

Full list of author information is available at the end of the article
}

the rest of the world [1]. The United Nations Children's Fund State of the World's Children Report, 2003 [1,2], noted a $14 \%$ overall world prevalence of low birth weight, with the highest prevalence of low birth weight in South Asia (26\%), with rates of $14 \%$ in developing countries, 9\% in Latin America and the Caribbean (Table 1). About two-thirds of births in parts of Asia, Africa, and Latin America go unreported because many deliveries occur in small clinics or private homes [1], hence, it is logical to assume that the number of lowweight births is also underreported.

\section{CiolMed Central}


and disease in adulthood, including coronary disease, stroke, and diabetes mellitus-all of which are among WHO's top 10 causes of death worldwide $[12,13,15,17,18]$.

Accurate determination of gestational age is essential for a diagnosis of SGA. The menstrual history of the mother and the use of ultrasound, usually in week 16 of gestation, increase the accuracy of the estimation. When this information is not available, physical examination of the newborn can be helpful (Ballard score [19]). Measurements of birth weight, length, and head circumference should be performed by trained personnel and follow appropriate, standardized procedures. The accuracy of newborn body measurements is paramount. Electronic scales for measuring weight and paper tapes for measuring head circumference are considered reliable methods [20-22]. Head circumference should be assessed at birth, as well as at first pediatric analysis during the first month of life in order to derive a more consistent measurement. Measurement of an infant's length can be less reliable [20,23], but its accuracy may be improved if the infant is measured by 2 people using a headboard $[20,24]$. The values should be compared with population-specific reference tables, allowing for classification as AGA or SGA, according to the chosen definition [25]. Country-specific reference charts for size at birth are preferred [26], but in some Latin American countries, these specific reference charts for size at birth are still unavailable. There is a critical need to develop reference charts for size at birth in each country, otherwise the definition of SGA could still be misleading in certain areas.

Growth references specific to Argentina have been used for more than 2 decades [27,28]. In 2009, Lejarraga et al published refinements to these charts by recalculating percentiles and lambda-mu-sigma (LMS) values from birth to maturity and incorporating updated WHO data from birth to age 2 years [29]. The Argentine growth charts are available at: http:// www.garrahan.gov.ar/tdecrecimiento. When a national reference for preterm growth and size at birth is not available, the Babson and Benda growth charts updated in 2003 are recommended [20,30]. Children born prematurely ( $<37$ weeks gestational age) should be evaluated considering their special characteristics. Among them will be newborns SGA and AGA and appropriate references for preterm must be used [20]. However, it is important to recognize that defining SGA in preterm infants may be difficult since preterm reference charts do not typically include extremely preterm infants. Every country should make an effort to collect growth charts that represent a large number of premature infants of different gestational ages for more informed datasets.

\section{Causes of SGA}

Many risk factors associated with low birth weight significantly overlap with risk factors associated with prematurely born infants. The characterization of an SGA infant should take into account the mother's height, weight, parity, age, ethnicity, and geographic location. Maternal malnutrition (ie, an insufficient weight increase during gestation), placental size and dysfunction, and the presence of maternal diseases should also be established [11]. Smoking, alcohol consumption, and drug use are preventable causes of IUGR; therefore, the mother's habits relative to these factors should be recorded. Fetal growth depends both on genetic factors and an optimal maternal-fetal health environment that allows the free flow of nutrients and oxygen, in addition to the integrity of growth factors IGF-1, IGF-2, and insulin synthesis and action. In addition, an excess of cortisol in fetal circulation produces a derangement in fetal growth.

\section{Growth and SGA \\ Follow-up}

Most children born SGA recover from their weight and height deficiency. Term SGA newborns generally complete catch-up growth at about 2 years of age [31-33], whereas premature newborns may take longer to catch up than full-term newborns [34]. The recovery is completed when they reach their genetic potential as determined by parental height [33]. However, $10 \%$ to $15 \%$ of those born SGA will continue to have significantly short stature (height $\leq-2 \mathrm{SD}$ ) during childhood and adult life $[31,35,36]$.

Approximately $90 \%$ of healthy, full-term children born SGA will undergo catch-up growth during their first 2 years of life [31], which can occur as early as 12 weeks postnatal age [37]. As such, this consensus recommends that children born SGA should be evaluated every 3 months during the first year of life and every 6 months during the second year. Weight, length, and head circumference should be measured at all appointments. A child who does not show catch-up growth during the first 6 months of life should be evaluated further. The same recommendation is valid for a child whose weight is $\leq-2 \mathrm{SD}$ at age 2 years. In these cases, common pediatric diseases, genetic disorders and hypothalamic and/or pituitary dysfunctions should be ruled out. SGA children who do not recover height generally have an adequate endogenous growth hormone $(\mathrm{GH})$ secretion in response to pharmacological tests. However, they often have low serum IGF-1 levels and altered physiological GH secretion patterns [32,38].

Ideally, SGA implies length and weight reference data in a geographical population whose ethnicity is known. If local charts endorsed by local Pediatrics Associations 
are not available, from birth until age 5 years, the WHO growth charts could be used (http://www.who.int/childgrowth) [39]. The WHO charts combine data of a longitudinal follow-up from birth to 24 months and a crosssectional survey of children aged 18 to 71 months; breastfed infants and young children from Brazil, Ghana, India, Norway, Oman, and USA were included. After age 5 years, the WHO Reference 2007-an update of the 1977 National Center for Health Statistics (NCHS)/WHO reference, using the original NCHS data set supplemented with data from the WHO child growth standards-is recommended http://www.who.int/ growthref/en/[40].

\section{Criteria for initiation of growth hormone treatment Age}

$\mathrm{GH}$ treatment (somatropin [rDNA origin] for injection) was approved by the US Food and Drug Administration (FDA) in July 2001 for the long-term treatment of growth failure in children born SGA who did not have sufficient catch-up growth by age 2 years $[10,41,42]$. That is, children older than 2 years of age with either short stature $(<-2 \mathrm{SD})$ and a birth weight $<2500 \mathrm{~g}$ at a gestational age $\geq 37$ weeks [41], with birth weight or length $<3$ rd percentile for gestational age [41], or with ponderal weight index $(100 \times$ [weight in $\mathrm{g}] \div$ [length in $\left.\mathrm{cm}]^{3}\right)<-2$ SD.

In Europe, GH treatment was approved by the Committee for Proprietary Medicinal Products (CPMP) in June 2003 for children born SGA (birth weight and length $<-2 \mathrm{SD}$ ) with short stature (height $<-2.5$ standard deviation score [SDS] and parental adjusted height $<-1.0$ SDS) and who fail to show catch-up growth by age 4 years or older [43].

Argente and colleagues recently analyzed the outcome of very young SGA children, between ages 2-5 years, treated with GH [44]. They reported a greater increase in height velocity in the group younger than 4 years of age. Considering this finding, starting treatment shortly after age 2 years should be considered, particularly when growth velocity is below the 25th percentile for the child's age.

\section{$\mathrm{GH}$ dosing recommendations}

A clear dose-dependent increase in height velocity has been observed in children born SGA during the first years of treatment $[10,45]$. Optimal height is obtained with longer $\mathrm{GH}$ treatment before the start of puberty [46]. Furthermore, the height gain obtained with treatment during the prepubertal years is maintained until final height [46]. GH dosing recommendations for children born SGA differ in the US and Europe-the recommended dosage in the US is up to $0.48 \mathrm{mg} / \mathrm{kg}$ per week $(68.5 \mu \mathrm{g} / \mathrm{kg} /$ day $)$ divided into daily doses [41] and the corresponding dosage in Europe is $0.035 \mathrm{mg} / \mathrm{kg} /$ day continued until full height is reached [43]. We recommend an initial GH dose of $0.33 \mathrm{mg} / \mathrm{kg} /$ week $(\approx 47 \mu \mathrm{g} /$ $\mathrm{kg} /$ day or $0.15 \mathrm{IU} / \mathrm{kg} /$ day), with dose adjustments based on weight gain for those children with stature $<-2$ and $>-3 \mathrm{SD}$. However, for those children with height $<-3$ $\mathrm{SD}$, when rapid catch-up growth is desired, a higher dose might be indicated $(0.48 \mathrm{mg} / \mathrm{kg} /$ week $)$ without dose adjustment based on weight until they reach the regular dose of $0.33 \mathrm{mg} / \mathrm{kg} /$ week and IGF-1 levels within upper normal range. With this schedule a higher dose from the beginning of therapy will induce faster catchup growth in those children who are more severely compromised.

\section{Baseline assessment and follow-up during GH treatment}

Baseline studies including hormonal (thyroid, IGF-1) and metabolic measurements (glucose, insulin, and lipid profile) are mandatory before initiation of GH treatment. Careful follow-up during GH treatment is recommended. The child should be evaluated every 3 to 6 months (physical examination and laboratory evaluation) by a physician experienced using $\mathrm{GH}$ to determine if dose adjustment is necessary [47]. Blood glucose, thyroid function, HbA1c, and IGF-1 should be monitored once a year except in cases exhibiting clear clinical evidence of insulin resistance or an $\mathrm{HbA} 1 \mathrm{C}$ of $6 \%$ at the beginning of treatment. While it is necessary to measure IGF-1 levels once a year, twice a year is preferred. Monitoring changes from baseline insulin levels and surrogates of insulin sensitivity are also helpful in the followup of these children [48]. Notably, GH-associated adverse events are not more common in SGA than other conditions treated with GH [3]. Patients with a strong familial history of type 2 diabetes could be evaluated with the use of an oral glucose tolerance test (OGTT) at baseline and then as appropriate, contingent on 3- and 6-month laboratory values.

\section{Criteria to stop GH treatment}

Treatment with GH should continue if a positive growth response is observed within the first year of treatment (height velocity > +0.5 SDS) [3]. Treatment in adolescence should be stopped if the height velocity is below 2 $\mathrm{cm} /$ year and bone age is $>14$ years for girls and $>16$ years for boys, corresponding to closure of the epiphyseal growth plates [43].

\section{Adverse events}

Continuous GH therapy is not associated with serious adverse events in short children who are born SGA [49-51]. However, because of increased prevalence of metabolic disturbances and high blood pressure in adults born SGA $[15,17,18,52-55]$, specific attention must be paid to glucose homeostasis and weight gain in short SGA children treated with GH. Previous studies have demonstrated that discontinuation of long-term GH treatment in SGA adolescents normalized insulin 
levels (both fasting and stimulated) after a significant increase during GH therapy [56,57].

$\mathrm{GH}$ treatment does not appear to be associated with an increased risk of malignancy [57]. It is recommended that IGF-1 concentrations should be monitored and GH dose should be reduced in children with a plasma IGF-1 above $+2 \mathrm{SD}[58,59]$. In a long-term follow-up study of GH therapy in short children born SGA, increased IGF1 levels were completely reversed after discontinuing $\mathrm{GH}[60]$.

\section{Puberty and SGA}

\section{Pubertal growth}

Current data with regard to initiation, tempo, duration, and progression of puberty in children born SGA are limited and difficult to compare due to the differences in methodologies in the available literature (eg, SGA with or without catch-up, differences in the definition of SGA). Some studies show a normal but earlier pubertal development; however, others report a late pubertal start [61-63].

In human models, decreased pubertal growth has been observed [64]. In female models, a delayed growth of approximately $4 \mathrm{~cm}$ has been reported [65]. This finding suggests that there are gender-dimorphic susceptibilities for SGA postnatal pubertal changes [62,65]

With regard to the age of pubertal initiation, most studies report an age similar to that for children born AGA [62]; however, several researchers have shown either an earlier pubertal timing [61,65-67], or late tempo $[68,69]$. In an animal study analysis, investigators postulated that a higher level of exposure to insulin in postnatal life in those born SGA with accelerated weight gain may induce an earlier, exaggerated secretion of LH that leads to earlier pubertal timing [70].

Menarcheal age has also been reported as being earlier or within normal range [62,64,66,71-75]. Girls born SGA who had rapid weight gain in first months of infancy are more likely to have premature adrenarche. These girls can have earlier puberty and menarche than AGA girls with premature adrenarche $[73,76]$.

Although bone age assessment is used to evaluate skeletal maturity, it has been suggested that use of bone age for final height prognosis is of limited value in children born SGA and thus should be used with caution [77].

SGA children without catch-up growth who are treated with GH have a normal pubertal timing and progression [68]. However, the use of GH near the beginning or late in puberty has not been shown to improve final height significantly $[57,59]$.

\section{Female gonadal function}

Girls born SGA with catch-up growth present with lower insulin sensitivity, and there are data showing an increased incidence of adrenal and ovarian hyperandrogenism clinically evident as precocious pubarche $[76,78,79]$. However, these data were collected in a selected population from an endocrine clinic $[76,78,79]$ and other studies have not confirmed these associations [80-84]. Thus far, there are insufficient data to confirm an altered ovarian function, fertility, or earlier menopause in these girls.

\section{Metformin use}

There is a preliminary report which suggests that the early use of metformin at a perimenarcheal age in lowbirth-weight girls with a history of precocious pubarche prevents progression to polycystic ovary syndrome (PCOS); improves insulin sensitivity; and normalizes body composition, lipid profiles and GH secretion [85]. In a subsequent report in low-birth-weight girls with precocious pubarche by the same group, metformin treatment was associated with a less-adipose body composition; a 0.4-year delay in the clinical onset of puberty; a delay of at least 1 year in puberty-associated increase in circulating IGF-I; and a maintenance of height gain [86]. These findings remain to be confirmed by other studies and thus are still considered preliminary.

\section{Male gonadal function}

Little is known about the long-term effects of IUGR or being born SGA and their relationship to hypothalamicpituitary-gonadal function in males [87]. Low birth weight has been associated with an increased frequency of hypospadia, cryptorchidism, and testicular cancer [87]. This cluster is known as testicular dysgenesis syndrome and a common fetal origin has been proposed for this association [87-91]. There are insufficient data about seminal quality and the relationship with catch-up growth or GH treatment in these individuals. On the other hand, some differences in the levels of pituitary and testicular hormones and in testicular volumes have been reported [92]. However, there is no consensus in this regard and no separation with individuals who had cryptorchidism [93]. Further studies to evaluate the impact of IUGR and SGA on the hypothalamic-pituitary-testicular axis are warranted.

\section{SGA and Metabolic Risks}

A significantly increased risk of developing cardiovascular disease (hypertension and dyslipidemia) and type 2 diabetes during adulthood has been associated with low birth weight $[52-54,94]$. Three main hypotheses have been proposed to explain the association between low birth weight and increased metabolic risks. The fetal cortisol hypothesis postulated that maternal nutrient restriction may act to reprogram the development of the pituitary-adrenal axis, resulting in excess glucocorticoid exposure and adverse health outcomes in later life. In this hypothesis, placental 11 beta-hydroxysteroid 
dehydrogenase (11 beta-HSD) plays a key role by converting active cortisol to inactive cortisone. This enzyme guards the fetus from the growth-retarding effects of maternal glucocorticoids [95-97].

The second alternative hypothesis is the fetal insulin hypothesis which proposes that genetically determined insulin resistance results in impaired insulin-mediated growth in the fetus, as well as insulin resistance in adult life [98]. There is evidence to support this hypothesis in a minority of low-birth-weight cases. For example, monogenic diseases with impaired sensing of glucose, lowered insulin secretion or increased insulin resistance are associated with impaired fetal growth.

The most plausible explanation of this association, however, is the catch-up growth hypothesis. Children born SGA may present with a decreased insulin sensitivity early in life [15,99-101]. In the first study to evaluate insulin secretion and sensitivity in both SGA and AGA children from birth to age 1 year [99], investigators from the University of Chile, Santiago, reported that by age 1 year, the SGA children with catch-up weight gain (ie, weight gain SD score $>0.67$ ) had higher fasting insulin levels and insulin resistance (insulin area under the curve during IV glucose) than AGA children. In a follow-up study of these subjects, the investigators reported that gains in weight SD scores continued to age 3 years in the children born SGA, and insulin resistance also progressed during this period [15]. At age 3 years, no differences in weight or BMI were seen between these SGA and AGA children, nor were there differences between the groups in firstphase insulin secretion. However, SGA children had a lower glucose disposition index (lower beta cell compensation) that persisted after postnatal weight gain. The SGA children also exhibited marked transition from lower pre-fed insulin and increased insulin sensitivity at birth to insulin resistance by age 3 years. The investigators noted this transition was related to rapid postnatal catch-up weight gain [15], which may be related to an increased tendency toward central fat deposition. They recommended long-term monitoring of glucose homeostasis in all SGA children regardless of postnatal catch-up growth. Thus, children born SGA should not be allowed to gain weight too rapidly or excessively in an effort circumvent the development of metabolic disturbances.

The pathophysiological mechanisms of insulin resistance are possibly secondary to a relative prolonged nutritional deficiency in the fetus, during which time the fetal metabolism constantly readjusts to slow growth with relative resistance to insulin, IGF-1, and GH. When this "adaptation" is inconsistent with postnatal nutrition, it may be associated with a rapid weight gain during infancy, and may result in considerable adaptation that develops a cluster of signs of metabolic syndrome $[55,102]$ with insulin resistance as the key factor. This cluster increases the risk of experiencing comorbidities, such as obesity, diabetes, dyslipidemia, coronary disease, and hypertension, among others $[103,104]$. Indeed, the sum of risk factors (eg, rapid weight gain, family history, and ethnic group) all contribute to exacerbate the risk of metabolic syndrome in children born SGA. Notably, these children are not necessarily overweight or obese, but have a higher "adipose" body composition that contributes to the metabolic features [55]. In these cases, detection of clinical signs of insulin resistance, such as acanthosis nigricans, is of great importance. In addition, the periodic monitoring of blood pressure is vital in these children, especially if they are overweight or obese.

The efficacy of GH treatment in children born SGA has been confirmed by several series and by results in final height under continuous treatment with $\mathrm{GH}$ $[3,44,46,51,57,105]$. Nevertheless, safety in relation to glucose metabolism in GH-treated SGA children has been and continues to be an issue of particular importance, considering the known effect of $\mathrm{GH}$ on glucose metabolism. SGA children treated with GH experience a transient increase in serum insulin concentrations and variable degrees of compromised glucose tolerance [106]. These side effects, which are the result of a predictable response to the physiological actions of $\mathrm{GH}$, have been previously reported [51,107-110]. However, no long-term effects have been observed on the prevalence of type 2 diabetes [107]. Furthermore, the effects on insulin resistance seem to be reversible $[56,108,111,112]$.

In view of the fact that a high percentage of individuals with glucose intolerance have a fasting blood glucose level below $100 \mathrm{mg} / \mathrm{dL}$, the OGTT is applicable in children and adolescents with risk factors such as obesity, family history, and hypertension. However, we do not recommend this be indicated as a general complementary test for children born SGA, rather, it should be individualized for children with rapid weight gain, acanthosis nigricans, dyslipidemia (high triglycerides), or a significant family history of metabolic syndrome [9].

Improvements in lipid profile and blood pressure associated with the metabolic syndrome in SGA children receiving GH treatment has also been reported [56]. Determining the concentrations of total cholesterol, HDL and LDL cholesterol, and especially plasma triglycerides are important. All of these values must be compared with appropriate standards for children of different ages.

\section{Implementation}

Use of available population-, ethnic-, or country-specific reference data for birth weight and length, if available, is 
important for identification of SGA. However, accurate measurement of weight, length, and head circumference and, particularly, accurate gestational dating are more essential to a correct diagnosis of SGA [10]. In cases of suspected SGA, pediatricians should obtain ultrasonographic dating information, if performed during pregnancy. Pediatricians should also consider obtaining other pregnancy data, immediate perinatal/postnatal data, and early postnatal growth data, if available [10]. If possible, identifying the cause of SGA (eg, fetal factors [genetic, congenital anomalies], maternal factors, nutritional or substance abuse factors, uterine/placental factors, demographic factors, and multiple gestation), is important, as it may affect treatment. Children who do not experience catch-up growth should receive careful long-term physical and laboratory monitoring by an endocrinologist or pediatrician with endocrinology expertise. If necessary, they might be placed on GH therapy early [3] .

Obstetricians/gynecologists should refer pregnancies with diagnosis of IUGR to a high-risk obstetric clinic with special care for certain diseases (eg, platelet dysfunction, hypertension) in order to reduce the severity of IUGR and the frequency of children born SGA. Although high-risk clinics are usually located in big cities, public health organizations should be aware of the needs of these patients and develop special networks for them. Neonatologists should be alert for the possible consequences of acute fetal distress that may occur during labor and/or delivery by caesarian section of an SGA infant, in addition to all the known complications such as respiratory distress, hypoglycemia, and hypokalemia.

A program for medical dissemination and training of multidisciplinary team members is an important next step. Training on the adequate management of SGA term and preterm newborns must be provided to pediatricians and neonatologists. Immediate, medium-, and long-term complications must be discussed, with an emphasis on growth problems and metabolic alterations that may develop. Pediatricians are encouraged to share their knowledge via multidisciplinary workshops. Furthermore, it would be important to provide written materials on the monitoring of adequate growth, the recovery phase, and follow-up in order to detect growth and metabolic alterations in these patients. Policies involving the primary care physician and pediatrician for detection and referral to a pediatric endocrinologist for the examination and treatment of growth and metabolic alterations in those born SGA should be developed.

\section{Summary}

Most children born SGA recover from their weight and height deficiency. However, $10 \%$ to $15 \%$ of children born SGA will continue to have short stature. GH treatment benefits growth potential in short-stature children born SGA. In both sexes, gonadal function should be taken into account, especially during puberty. Reduced fetal growth followed by excessive postnatal catch-up in height, and particularly in weight, should be monitored. Excessive weight gain is most frequently associated with metabolic risk later in life. Finally, children born SGA should be carefully followed by a multidisciplinary group that includes perinatologists, pediatricians, nutritionists, and pediatric endocrinologists, in order to improve growth, glucose homeostasis, and gonadal function.

\section{Latin American SGA Consensus Guidelines Summary}

- Local charts endorsed by local Pediatrics Associations are recommended. If local charts are not available, WHO growth charts may be used from birth until age 5 years, after which the WHO Reference 2007 is recommended.

- Most infants born SGA recover from their weight and height deficiency.

- GH treatment benefits growth potential in shortstature children born SGA.

- Gonadal function in both sexes should be taken into account, especially during puberty.

- Children born SGA should not be allowed to gain weight too rapidly or excessively in an effort to circumvent the development of metabolic disturbances. - Children born SGA should be followed carefully by a multidisciplinary group.

- A program for medical dissemination and training of multidisciplinary team members is needed.

\section{Acknowledgements}

We thank Adriane de Andre Cardoso-Demartini for her support of the manuscript preparation. Medical writing services and editorial assistance were provided by ACUMED $^{\circledR}$ (New York, NY).

\section{Author details \\ 'Department of Pediatrics, Hospital de Clínicas, Federal University of Paraná, Curitiba, Brazil. ' Institute of Maternal and Child Research, Faculty of Medicine, University of Chile, Santiago. ${ }^{3}$ División de Endocrinología, Hospital de Niños "Ricardo Gutiérrez," Buenos Aires, Argentina. ${ }^{4}$ Pediatric Endocrinology Unit, Instituto da Criança, São Paulo University Medical School, Brazil. ${ }^{5}$ Hospital de Pediatria Garrahan, Buenos Aires, Argentina. ${ }^{6}$ Unidad de Endocrinología Pediátrica, Hospital de Clínicas Caracas, Caracas, Venezuela. ${ }^{7}$ Universidad Militar Nueva Granada Hospital Militar Central, Bogotá, Colombia. \\ ${ }^{8}$ Department of Pediatrics, Universidad del Bosque, Bogotá, Colombia. ${ }^{9}$ Centro de Investigaciones Endocrinológicas (CEDIE-CONICET), Hospital de Niños "Ricardo Gutiérrez," Buenos Aires, Argentina. ${ }^{10}$ Endocrinology Services, Instituto Nacional de Pediatría, México City, México. ${ }^{11}$ Hospital Angeles Lomas, Ciudad de México, México. ${ }^{12}$ Hospital Para el Niño Poblano, Puebla, México. ${ }^{13}$ Instituto Ecuatoriano de Endocrinología y Metabolismo, IEMYR, Quito, Ecuador. ${ }^{14}$ Unidad de Endocrinología Pediátrica, Hospital de Clínicas Caracas, Caracas, Venezuela. ${ }^{15}$ Servicio de Endocrinología, Hospital Nacional de Niños "Dr. Carlos Sáenz Herrera," San José, Costa Rica.}

\section{Authors' contributions}

All the authors participated in the consensus meeting to discuss and vote on recommendations. $M B, V M, A B$, and $I B$ helped draft the manuscript. All authors read and approved the final manuscript. 


\section{Competing interests}

Margaret CS Boguszewski is a member of the KIGS Strategic Advisory Board: she has no financial information to declare. Durval Damiani received less than $\$ 10,000$ in honoraria from Pfizer Inc. This study was funded by Pfizer Inc.

All other authors declare that they have no competing interests.

Received: 29 September 2010 Accepted: 19 July 2011

Published: 19 July 2011

\section{References}

1. Ramakrishnan U: Nutrition and low birth weight: from research to practice. Am J Clin Nutr 2004, 79:17-21.

2. United Nations Children's Fund 2003 State of the World's Children Report, 2003. [http://www.unicef.org/sowc03/contents/pdf/SOWC03-eng. pdf], Accessed July 1, 2010

3. Clayton PE, Cianfarani S, Czernichow P, Johannsson G, Rapaport R, Rogol A: Management of the child born small for gestational age through to adulthood: a consensus statement of the International Societies of Pediatric Endocrinology and the Growth Hormone Research Society. J Clin Endocrinol Metab 2007, 92:804-810.

4. Barker DJ: Mothers, babies, and disease in later life. London: British Medical Journal Publishing Group; 1998.

5. Hardin DS: Treatment of short stature and growth hormone deficiency in children with somatotropin (rDNA origin). Biologics 2008, 2:655-661.

6. Intrauterine growth retardation in newborn children. [http://www.who. int/ceh/indicators/iugrnewborn.pdf], Accessed July 1, 2010.

7. Battaglia FC, Lubchenco LO: A practical classification of newborn infants by weight and gestational age. J Pediatr 1967, 71:159-163.

8. Williams RL, Creasy RK, Cunningham GC, Hawes WE, Norris FD, Tashiro M: Fetal growth and perinatal viability in California. Obstet Gynecol 1982, 59:624-632.

9. Physical status: the use and interpretation of anthropometry. Report of a WHO Expert Committee. Technical Report Series No. 854. 1995 [http:// www.who.int/childgrowth/publications/physical_status/en/ ], Accessed July 1,2010

10. Lee PA, Chernausek SD, Hokken-Koelega AC, Czernichow P: International Small for Gestational Age Advisory Board consensus development conference statement: management of short children born small for gestational age, April 24-October 1, 2001. Pediatrics 2003, 111:1253-1261.

11. Saenger P, Czernichow P, Hughes I, Reiter EO: Small for gestational age: short stature and beyond. Endocr Rev 2007, 28:219-51.

12. Flores $H A$, Valverde $M G$, Islas $G A$ : Peso al nacer de los niños y niñas. In Prácticas de alimentación, estado de nutrición y cuidados a la salud en ninos menores de 2 años en México. Edited by: Flores HA, Martinez SH. Mexico: Instituto Mexicano del Seguro Social; 2004:

13. Centro Latinoamericano de Perinatología y Desarrollo Humano, OPS/ OMS Boletín de Salud Perinatal. 2000, 18:7-9.

14. The top 10 causes of death. [http://www.who.int/mediacentre/factsheets/ fs310/en/, Updated October 2008. Accessed July 1, 2010

15. Mericq V, Ong KK, Bazaes R, Peña V, Avila A, Salazar T, Soto N, Iñiguez G, Dunger DB: Longitudinal changes in insulin sensitivity and secretion from birth to age three years in small- and appropriate-for-gestationalage children. Diabetologia 2005, 48:2609-2614.

16. Hokken-Koelega A, van Pareren Y, Arends N: Effects of growth hormone treatment on cognitive function and head circumference in children born small for gestational age. Horm Res 2005, 64(Suppl 3):95-99.

17. Eriksson JG, Forsen T, Tuomilehto J, Jaddoe WW, Osmond C, Barker DJ: Effects of size at birth and childhood growth on the insulin resistance syndrome in elderly individuals. Diabetologia 2005, 45:342-348.

18. Eriksson JG, Forsen T, Tuomilehto J, Winter PD, Osmond C, Barker DJ: Catch-up growth in childhood and death from coronary heart disease: longitudinal study. BMJ 1999, 318:427-431.

19. Ballard JL, Novak KK, Driver M: A simplified score for assessment of fetal maturation of newly born infants. J Pediatr 1979, 95:769-774.

20. Fenton TR: A new growth chart for preterm babies: Babson and Benda's chart updated with recent data and a new format. BMC Pediatr 2003, 3:13.

21. Engstrom JL, Kavanaugh K, Meier PP, Boles E, Hernandez J, Wheeler D, Chuffo R: Reliability of in-bed weighing procedures for critically ill infants. Neonatal Netw 1995, 14:27-33.
22. Sutter K, Engstrom JL, Johnson TS, Kavanaugh K, Ifft DL: Reliability of head circumference measurements in preterm infants. Pediatr Nurs 1997, 23:485-490.

23. Rosenberg SN, Verzo B, Engstrom JL, Kavanaugh K, Meier PP: Reliability of length measurements for preterm infants. Neonatal Netw 1993, 11:23-27.

24. Fomon SJ, Nelson SE: Size and growth. In Nutrition of normal infants. Edited by: Fomon SJ. St Louis, MO: Mosby; 1993:49.

25. Wollman $\mathrm{H}$ : Children born small for gestational age: definitions and etiology. In 2009 Small for gestational age, causes and consequences. pediatric and adolescent medicine. Volume 13. Edited by: Keiss W, Chernausek SD, Hokken-Koelega A. Karger AG, Basel; 2009:1-10.

26. González RP, Gómez RM, Castro RS, Nien JK, Merino PO, Etchegaray AB, Carstens MR, Medina LH, Viviani PG, Rojas IT: A national birth weight distribution curve according to gestational age in Chile from 1993 to 2000. Rev Med Chil 2004, 132:1155-1165.

27. Lejarraga H, Orfila G: Height and weight standards for Argentine children from birth to maturity. Arch Argent Pediatr 1987, 85:209-222.

28. Lejarraga H, Morasso M del C, Orfila G: Standards weight/age and weight/ height for children under 6 years in primary care. Arch Argent Pediatr 1987, 85:69-76

29. Lejarraga H, del Pino M, Fano V, Caino S, Cole TJ: Growth references for weight and height for Argentinian girls and boys from birth to maturity: incorporation of data from the World Health Organisation from birth to 2 years and calculation of new percentiles and LMS values. Arch Argent Pediatr 2009, 107:126-133.

30. Rao SC, Tompkins J, World Health Organization: Growth curves for preterm infants. Early Hum Dev 2007, 83:643-51.

31. Karlberg J, Albertsson-Wikland K: Growth in full-term small-for-gestationalage infants: from birth to final height. Pediatr Res 1995, 38:733-739.

32. Albertsson-Wikland K, Boguszewski M, Karlberg J: Children born small-forgestational age: postnatal growth and hormonal status. Horm Res 1998, 49(2):7-13.

33. Albertsson-Wikland K, Karlberg J: Postnatal growth of children born small for gestational age. Acta Paediatr Suppl 1997, 423:193-195.

34. Finken MJ, Dekker FW, de Zegher F, Wit JM, Dutch Project on Preterm and Small-for-Gestational-Age-19 Collaborative Study Group 2006: Dutch Project on Preterm and Small-for-Gestational-Age-19 Collaborative Study Group 2006: Long-term height gain of prematurely born children with neonatal growth restraint: parallellism with the growth pattern of short children born small for gestational age. Pediatrics 2006, 118:640-643

35. Leger J, Garel C, Fjellestad-Paulsen A, Hassan M, Czernichow P: Human growth hormone treatment of short-stature children born small for gestational age: effect on muscle and adipose tissue mass during a 3year treatment period and after 1 year's withdrawal. J Clin Endocrinol Metab 1998, 83:3512-3516.

36. Leger J, Levy-Marchal C, Bloch J, Pinet A, Chevenne D, Porquet D, Collin D, Czernichow P: Reduced final height and indications for insulin resistance in 20 year olds born small for gestational age: regional cohort study. BMJ 1997, 315:341-347.

37. Karlberg JP, Albertsson-Wikland K, Lam BC, Low BC: The timing of early postnatal catch-up growth in normal, full-term infants born short for gestational age. Horm Res 1997, 48(Suppl 1):17-24.

38. de Waal WJ, Hokken-Koelega AC, Stijnen T, de Muinck Keizer-Schrama SM Drop SL: Endogenous and stimulated GH secretion, urinary GH excretion, and plasma IGF-I and IGF-II levels in prepubertal children with short stature after intrauterine growth retardation. The Dutch Working Group on Growth Hormone. Clin Endocrinol 1994, 41:621-630.

39. The WHO child growth standards. [http://www.who.int/childgrowth/ standards/en/], Accessed July 1, 2010

40. Growth reference data for 5-19 years. [http://www.who.int/growthref/en/1, Accessed July 1, 2010.

41. Gharib H, Cook DM, Saenger PH, Bengtsson BA, Feld S, Nippoldt TB, Rodbard HW, Seibel JA, Vance ML, Zimmerman D, American Association of Clinical Endocrinologists Growth Hormone Task Force 2003: American Association of Clinical Endocrinologists medical guidelines for clinical practice for growth hormone use in adults and children-2003 update. Endocr Pract 2003, 9:64-73.

42. Genotropin (somatropin) injection CenterWatch Web site. [http://www. centerwatch.com/drug-information/fda-approvals/drug-details.aspx? Drug|D=712], Accessed July 1, 2010. 
43. European Agency for the Evaluation of Medicinal Products: Committee for Proprietary Medicinal Products (CPMP) 2003 Norditropin. [http:// www.ema.europa.eu/pdfs/human/referral/norditropin/347803en.pdf], Published June 26, 2003. Accessed May 12, 2010.

44. Argente J, Gracia R, Ibáñez L, Oliver A, Borrajo E, Vela A, López-Siguero JP, Moreno ML, Rodríguez-Hierro F, Spanish SGA Working Group: Improvement in growth after two years of growth hormone therapy in very young children born small for gestational age and without spontaneous catch-up growth: results of a multicenter, controlled, randomized, open clinical trial. J Clin Endocrinol Metab 2007, 92:3095-3101.

45. Lanes $R$, Plotnick $L P$, Lee PA: Sustained effect of human growth hormone therapy on children with intrauterine growth retardation. Pediatrics 1979, 63:731-735.

46. Dahlgren J, Wikland KA, Swedish Study Group for Growth Hormone Treatment: Final height in short children born small for gestational age treated with growth hormone. Pediatr Res 2005, 57:216-222.

47. Wilson TA, Rose SR, Cohen P, Rogol AD, Backeljauw P, Brown R, Hardin DS, Kemp SF, Lawson M, Radovick S, Rosenthal SM, Silverman L, Speiser P, Lawson Wilkins Pediatric Endocrinology Society Drug and Therapeutics Committee: Update of guidelines for the use of growth hormone in children: the Lawson Wilkins Pediatric Endocrinology Society Drug and Therapeutics Committee. J Pediatr 2003, 143:415-421.

48. Bergada I, Blanco M, Keselman A, Domene HM, Bergada C: Growth hormone treatment in younger than six years of age short children born small for gestational age. Arch Argent Pediatr 2009, 107:410-416.

49. van Dijk M, Bannink EM, van Pareren YK, Mulder PG, Hokken-Koelega AC: Risk factors for diabetes mellitus type 2 and metabolic syndrome are comparable for previously growth hormone-treated young adults born small for gestational age (SGA) and untreated short SGA controls. J Clin Endocrinol Metab 2007, 92:160-165.

50. Willemsen RH, van Dijk M, de Rijke YB, van Toorenenbergen AW, Mulder PG, Hokken-Koelega AC: Effect of growth hormone therapy on serum adiponectin and resistin levels in short, small-for-gestational-age children and associations with cardiovascular risk parameters. J Clin Endocrinol Metab 2007, 92:117-23.

51. Cutfield WS, Lindberg A, Rapaport R, Wajnrajch MP, Saenger P: Safety of growth hormone treatment in children born small for gestational age: the US trial and KIGS analysis. Horm Res 2006, 65(Suppl 3):153-159.

52. Hales CN, Barker DJ, Clark PM, Cox LJ, Fall C, Osmond C, Winter PD: Fetal and infant growth and impaired glucose tolerance at age 64. BMJ 1991 303:1019-1022.

53. Barker DJ, Osmond C, Golding J, Kuh D, Wadsworth ME: Growth in utero, blood pressure in childhood and adult life, and mortality from cardiovascular disease. BMJ 1989, 298:564-567.

54. Barker DJ, Winter PD, Osmond C, Margetts B, Simmonds SJ: Weight in infancy and death from ischaemic heart disease. Lancet 1989, 2:577-580.

55. Jaquet D, Gaboriau A, Czernichow P, Levy-Marchal C: Insulin resistance early in adulthood in subjects born with intrauterine growth retardation. J Clin Endocrinol Metab 2000, 85:1401-1406.

56. van Pareren $Y$, Mulder P, Houdijk M, Jansen M, Reeser M, Hokken-Koelega A Effect of discontinuation of growth hormone treatment on risk factors for cardiovascular disease in adolescents born small for gestational age. J Clin Endocrinol Metab 2009, 88:347-353.

57. Chatelain P, Carrascosa A, Bona G, Ferrandez-Longas A, Sippell W: Growth hormone therapy for short children born small for gestational age. Horm Res 2007, 68:300-309.

58. Czernichow P: Growth hormone treatment strategy for short children born small for gestational age. Horm Res 2004, 62(Suppl 3):137-140.

59. Simon D, Leger J, Carel JC: Optimal use of growth hormone therapy for maximizing adult height in children born small for gestational age. Best Pract Res Clin Endocrinol Metab 2008, 22:525-537.

60. Bannink EM, van Doorn J, Mulder PG, Hokken-Koelega AC: Free/dissociable insulin-like growth factor (IGF)-I, not total IGF-I, correlates with growth response during growth hormone treatment in children born small for gestational age. J Clin Endocrinol Metab 2007, 92:2992-3000.

61. Ibánez L, Ferrer A, Marcos MV, Hierro FR, de Zegher F: Early puberty: rapid progression and reduced final height in girls with low birth weight. Pediatrics 2000, 106:E72.

62. Lazar L, Pollak U, Kalter-Leibovici O, Pertzelan A, Phillip M: Pubertal course of persistently short children born small for gestational age (SGA) compared with idiopathic short children born appropriate for gestational age (AGA). Eur J Endocrinol 2003, 149:425-432.

63. Lienhardt A, Carel JC, Preux PM, Coutant R, Chaussain JL: Amplitude of pubertal growth in short stature children with intrauterine growth retardation. Horm Res 2002, 57(Suppl 2):88-94.

64. Veening MA, van Weissenbruch MM, Roord JJ, de Delemarre-van Waal HA: Pubertal development in children born small for gestational age. $J$ Pediatr Endocrinol Metab 2004, 17:1497-1505.

65. Persson I, Ahlsson F, Ewald U, Tuvemo T, Qingyuan M, von Rosen D, Proos $L$ : Influence of perinatal factors on the onset of puberty in boys and girls: implications for interpretation of link with risk of long term diseases. Am J Epidemiol 1999, 150:747-755.

66. Albertsson-Wikland K, Karlberg J: Natural growth in children born small for gestational age with and without catch-up growth. Acta Paediatr Suppl 1994, 399:64-70.

67. Ghirri P, Bernardini M, Vuerich M, Cuttano AM, Coccoli L, Merusi I, Ciulli C, D'Accavio L, Bottone U, Boldrini A: Adrenarche, pubertal development, age at menarche and final height of full-term, born small for gestational age (SGA) girls. Gynecol Endocrinol 2001, 15:91-97.

68. Boonstra V, van Pareren $Y$, Mulder P, Hokken-Koelega A: Puberty in growth hormone-treated children born small for gestational age (SGA). J Clin Endocrinol Metab 2003, 88:5753-5758.

69. Vicens-Calvet E, Espadero RM, Carrascosa A: Longitudinal study of the pubertal growth spurt in children born small for gestational age without postnatal catch-up growth. J Pediatr Endocrinol Metab 2002, 15:381-388.

70. Cara JF, Rosenfield RL: Insulin-like growth factor I and insulin potentiate luteinizing hormone-induced androgen synthesis by rat ovarian thecalinterstitial cells. Endocrinology 1988, 123:733-739.

71. Bhargava SK, Ramji S, Srivastava U, Sachdev HP, Kapani V, Datta V, Satyanarayana L: Growth and sexual maturation of low birth weight children: a 14 year follow up. Indian Pediatr 1995, 32:963-970.

72. Hernandez MI, Mericq V: Impact of being born small for gestational age on onset and progression of puberty. Best Pract Res Clin Endocrinol Metab 2008, 22:463-476.

73. Ibáñez $L$, Jimenez $R$, de Zegher F: Early puberty-menarche after precocious pubarche: relation to prenatal growth. Pediatrics 2006, 117:117-121.

74. Koziel S, Jankowska EA: Effect of low versus normal birthweight on menarche in 14-year-old Polish girls. J Paediatr Child Health 2002, 38:268-271.

75. Sloboda DM, Hart R, Doherty DA, Pennell CE, Hickey M: Age at menarche: influences of prenatal and postnatal growth. J Clin Endocrinol Metab 2007, 92:46-50.

76. Ibáñez L, Potau N, Francois I, de Zegher F: Precocious pubarche, hyperinsulinism, and ovarian hyperandrogenism in girls: relation to reduced fetal growth. J Clin Endocrinol Metab 1998, 83:3558-3562.

77. Job JC, Rolland A: Natural history of intrauterine growth retardation: pubertal growth and adult height. Arch Fr Pediatr 1986, 43:301-306.

78. Ibáñez $\mathrm{L}$, de Zegher $\mathrm{F}$, Potau N: Anovulation after precocious pubarche: early markers and time course in adolescence. J Clin Endocrinol Metab 1999, 84:2691-2695.

79. Ibáñez L, de Zegher F: Puberty after prenatal growth restraint. Horm Res 2006, 65(Suppl 3):112-115.

80. Jaquet D, Leger J, Chevenne D, Czernichow P, Levy-Marchal C: Intrauterine growth retardation predisposes to insulin resistance but not to hyperandrogenism in young women. J Clin Endocrinol Metab 1999, 84:3945-3949.

81. Bazaes RA, Alegria A, Pittaluga $E$, Avila A, Iñiguez G, Mericq V: Determinants of insulin sensitivity and secretion in very-low-birth-weight children. $J$ Clin Endocrinol Metab 2004, 89:1267-1272.

82. Boonstra VH, Mulder PG, de Jong FH, Hokken-Koelega AC: Serum dehydroepiandrosterone sulfate levels and pubarche in short children born small for gestational age before and during growth hormone treatment. J Clin Endocrinol Metab 2004, 89:712-717.

83. Eyzaguirre $F C$, Bancalari $R$, Youlton $R$, Román $R$, Silva $R$, García $H$, Mericq V: Precocious pubarche: experience in 173 cases. Rev Med Chil 2009, 137:31-38.

84. Hernández Ml, Martínez A, Capurro T, Peña V, Trejo L, Avila A, Salazar T, Asenjo S, Iñiguez G, Mericq V: Comparison of clinical, ultrasonographic, and biochemical differences at the beginning of puberty in healthy girls 
born either small for gestational age or appropriate for gestational age: preliminary results. J Clin Endocrinol Metab 2006, 91:3377-3381.

85. Ibáñez L, Ferrer A, Ong K, Amin R, Dunger D, de Zegher F: Insulin sensitization early after menarche prevents progression from precocious pubarche to polycystic ovary syndrome. J Pediatr 2004, 144:23-29.

86. Ibáñez L, Ong K, Valls C, Marcos MV, Dunger DB, de Zegher F: Metformin treatment to prevent early puberty in girls with precocious pubarche. Clin Endocrinol Metab 2006, 91:2888-2891.

87. Main KM, Jensen RB, Asklund C, Høi-Hansen CE, Skakkebaek NE: Low birth weight and male reproductive function. Horm Res 2006, 65(Suppl 3):116-122.

88. Boisen KA, Kaleva M, Main KM, Virtanen HE, Haavisto AM, Schmidt IM, Chellakooty M, Damgaard IN, Mau C, Reunanen M, Skakkebaek NE, Toppari J: Difference in prevalence of congenital cryptorchidism in infants between two Nordic countries. Lancet 2004, 363:1264-1269.

89. Boisen KA, Chellakooty M, Schmidt IM, Kai CM, Damgaard IN, Suomi AM Toppari J, Skakkebaek NE, Main KM: Hypospadias in a cohort of 1072 Danish newborn boys: prevalence and relationship to placental weight, anthropometrical measurements at birth, and reproductive hormone levels at three months of age. J Clin Endocrinol Metab 2005, 90:4041-4046.

90. Hughes IA, Northstone K, Golding J: Reduced birth weight in boys with hypospadias: an index of androgen dysfunction? Arch Dis Child Fetal Neonatal Ed 2002, 87:F150-F151.

91. Pierik FH, Burdorf A, Deddens JA, Juttmann RE, Weber RF: Maternal and paternal risk factors for cryptorchidism and hypospadias: a case-control study in newborn boys. Environ Health Perspect 2004, 112:1570-1576.

92. Cicognani A, Alessandroni R, Pasini A, Pirazzoli P, Cassio A, Cacciari E: Low birth weight for gestational age and subsequent male gonadal function. J Pediatr 2002, 141:376-379.

93. Jensen RB, Vielwerth S, Larsen T, Greisen G, Veldhuis J, Juul A: Pituitarygonadal function in adolescent males born appropriate or small for gestational age with or without intrauterine growth restriction. $J$ Clin Endocrinol Metab 2007, 92:1353-1357.

94. Dunger DB, Ong KK: Babies born small for gestational age: insulin sensitivity and growth hormone treatment. Horm Res 2005, 64(Suppl 3):58-65.

95. Mericq V, Medina P, Kakarieka E, Márquez L, Johnson MC, Iñiguez G: Differences in expression and activity of 11 beta-hydroxysteroid dehydrogenase type 1 and 2 in human placentas of term pregnancies according to birth weight and gender. Eur J Endocrinol 2009, 161:419-425.

96. Seckl JR, Holmes MC: Mechanisms of disease: glucocorticoids, their placental metabolism and fetal 'programming' of adult pathophysiology. Nat Clin Pract Endocrinol Metab 2007, 3:479-488.

97. Phillips DI, Barker DJ, Fall CH, Seckl JR, Whorwood CB, Wood PJ, Walker BR: Elevated plasma cortisol concentrations: a link between low birth weight and the insulin resistance syndrome? I Clin Endocrinol Metab 1998, 83:757-760.

98. Hattersley AT, Tooke JE: The fetal insulin hypothesis: an alternative explanation of the association of low birthweight with diabetes and vascular disease. Lancet 1999, 353:1789-1792.

99. Soto N, Bazaes RA, Peña V, Salazar T, Avila A, Iñiguez G, Ong KK, Dunger DB, Mericq MV: Insulin sensitivity and secretion are related to catch-up growth in small-for-gestational-age infants at age 1 year: results from a prospective cohort. J Clin Endocrinol Metab 2003, 88:3645-3650.

100. Veening MA, Van Weissenbruch MM, Delemarre-Van De Waal HA: Glucose tolerance,insulin sensitivity, and insulin secretion in children born small for gestational age. J Clin Endocrinol Metab 2002, 87:4657-4661.

101. Veening MA, van Weissenbruch MM, Heine RJ, Delemarre-van de Waal HA: Beta-cell capacity and insulin sensitivity in prepubertal children born small for gestational age: influence of body size during childhood. Diabetes 2003, 52:1756-1760.

102. Jaquet $D$, Deghmoun S, Chevenne D, Collin D, Czernichow P, LévyMarchal C: Dynamic change in adiposity from fetal to postnatal life is involved in the metabolic syndrome associated with reduced fetal growth. Diabetologia 2005, 48:849-855.

103. Chatelain P: Children born with intrauterine growth retardation (IUGR) or small for gestational age: long-term growth and metabolic consequences. Endocr Regul 2000, 34:33-36.

104. Murtaugh MA, Jacobs DR Jr, Moran A, Steinberger J, Sinaiko AR: Relation of birth weight to fasting insulin, insulin resistance, and body size in adolescence. Diabetes Care 2003, 26:187-192.
105. Carel JC, Chatelain P, Rochiccioli P, Chaussain JL: Improvement in adult height after growth hormone treatment in adolescents with short stature born small for gestational age: results of a randomized controlled study. J Clin Endocrinol Metab 2003, 88:1587-1593.

106. Cutfield WS, Jackson WE, Jefferies C, Robinson EM, Breier BH, Richards GE, Hofman PL: Reduced insulin sensitivity during growth hormone therapy for short children born small for gestational age. J Pediatr 2003, 142:113-116.

107. Cutfield WS, Wilton $P$, Bennmarker $H$, Albertsson-Wikland $K$, Chatelain $P$, Ranke MB, Price DA: Incidence of diabetes mellitus and impaired glucose tolerance in children and adolescents receiving growth-hormone treatment. Lancet 2000, 355:610-613.

108. de Zegher F, Ong K, van Helvoirt M, Mohn A, Woods K, Dunger D: Highdose growth hormone $(\mathrm{GH})$ treatment in non-GH-deficient children born small for gestational age induces growth responses related to pretreatment GH secretion and associated with a reversible decrease in insulin sensitivity. J Clin Endocrinol Metab 2002, 87:148-151.

109. Hofman PL, Cutfield WS, Robinson EM, Bergman RN, Menon RK, Sperling MA, Gluckman PD: Insulin resistance in short children with intrauterine growth retardation. J Clin Endocrinol Metab 1997, 82:402-406.

110. Hokken-Koelega A, van Pareren Y, Arends N, Boonstra V: Efficacy and safety of long-term continuous growth hormone treatment of children born small for gestational age. Horm Res 2004, 62(Suppl 3):149-154.

111. Willemsen RH, Willemsen SP, Hokken-Koelega AC: Longitudinal changes in insulin sensitivity and body composition of small-for-gestational-age adolescents after cessation of growth hormone treatment. J Clin Endocrinol Metab 2008, 93:3449-3454.

112. Willemsen RH, de Kort SW, van der Kaay DC: Independent effects of prematurity on metabolic and cardiovascular risk factors in short smallfor-gestational-age children. J Clin Endocrinol Metab 2008, 93:452-458.

\section{Pre-publication history}

The pre-publication history for this paper can be accessed here: http://www.biomedcentral.com/1471-2431/11/66/prepub

doi:10.1186/1471-2431-11-66

Cite this article as: Boguszewski et al: Latin American Consensus: Children Born Small for Gestational Age. BMC Pediatrics 2011 11:66

\section{Submit your next manuscript to BioMed Central and take full advantage of:}

- Convenient online submission

- Thorough peer review

- No space constraints or color figure charges

- Immediate publication on acceptance

- Inclusion in PubMed, CAS, Scopus and Google Scholar

- Research which is freely available for redistribution 